
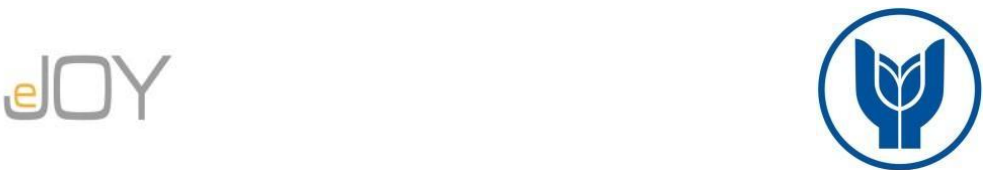

Karagöz, K., Özkubat, G. / Journal of Yasar University, 2021, 16/62, 867-889

\title{
Impact of Macroeconomic Factors on Housing Prices: An Analysis for Aegean Region
}

\section{Makroekonomik Faktörlerin Konut Fiyatlarına Etkisi: Ege Bölgesi İçin Bir Analiz}

\author{
Kadir KARAGÖZ, Manisa Celal Bayar University, Turkey, kadir.karagoz@cbu.edu.tr \\ Orcid No: 0000-0002-4435-9235 \\ Gökhan ÖZKUBAT, Manisa Celal Bayar University, Turkey, gokhan.ozkubat@cbu.edu.tr \\ Orcid No: 0000-0001-8845-8072
}

\begin{abstract}
In this study, macroeconomic factors which affect the change in house prices have been tried to be determined at two digit level in the Aegean region where rapid population increase observed due to industrialization and intensive immigration activity in recent years. In the analysis in which the House Price Index constructed by the CBRT used as the dependent variable, gold price, stock market index, TL/Euro exchange rate, housing loan interest rate, consumer confidence index for housing sector and regional consumer price index were used as exploratory variables.

The existence of the co-integration relationship between the variables was investigated by the ARDL Bound test and it was found that there is a significant relation between the variables in the long term for all three subregions. Co-integrated regression coefficients were estimated through FMOLS, DOLS, and CCR methods. According to the estimation results, house prices in Izmir (TR31) are affected by gold and general price level. In the Aydin sub-region (TR32) gold price, exchange rate, interest rate, population and general price level have significant effect. In the Manisa sub-region (TR33) exchange rate, interest rate and general price level are the main variables affecting housing prices.
\end{abstract}

Keywords: Housing Prices, House Price Index, Aegean Region, Macroeconomic Variables, Time Series Analysis

JEL Classification: C22, E30, R32

$\ddot{O ̈}_{z}:$ Bu çalışmada, son yıllarda sanayileşme ve yoğun içgöç hareketliliği nedeniyle hızla nüfusu artan Ege bölgesinde konut fiyatlarındaki değişim üzerinde etkili olan makroekonomik faktörler üç istatistiksel altbölge için belirlenmeye çalışılmıştır. TCMB tarafından hazırlanan Konut Fiyat Endeksi'nin bă̆ımlı değişken olarak alındı̆̆ analizde altın fiyatı, borsa endeksi, TL/Euro kuru, konut kredisi faiz oranı, konut sektörüne ilişkin tüketici güven endeksi ve bölgesel tüketici fiyat endeksi kontrol değişkenleri olarak kullanılmıştır.

Değişkenler arasındaki eşbütünleşme ilişkisinin varlı̆̆ ARDL Sınır testi ile araştırılmış ve her üç bölge için de uzun dönemde değişkenler arasında anlamlı bir ilişkinin var olduğu bulgusuna ulaşılmıştır. Eşbütünleşik regresyon katsayıları FMOLS, DOLS ve CCR yöntemleriyle elde edilmiştir. Tahmin sonuçlarına göre İzmir'de (TR31) konut fiyatları altın ve genel fiyat düzeyinden etkilenmektedir. Aydın altbölgesinde (TR32) altın fiyatı, döviz kuru, faiz oranı, nüfus ve genel fiyat düzeyi anlaml etkiye sahiptir. Manisa altbölgesinde (TR33) ise döviz kuru, faiz oranı ve genel fiyat düzeyi konut fiyatlarını etkileyen başlıca değişkenler olarak öne çıkmaktadır.

Anahtar Kelimeler: Konut Fiyatları, Konut Fiyat Endeksi, Ege Bölgesi, Makroekonomik Değişkenler, Zaman Serileri Analizi

JEL Sinıflandirmast: C22, E30, R32

\section{Introduction}

The concept of housing has a history almost as old as human history as a type of property that meets the need for shelter, which is its main function. Although its content, structure and meaning have changed over time, housing has become one of the basic elements of meeting the needs of human beings such as shelter, security, comfort, socialization, self-expression 
and aesthetics. In addition, housing has become an important investment tool in the age we live in. On the other hand, the construction sector, where housing production has a dominant place, is one of the major components of the economic structure.

As a durable consumer good, housing has an important share in household expenditures and wealth, whether for use or for investment purposes. Therefore, it can be expected that the housing sector will have significant relations with the financial markets due to its direct interaction with economic variables such as savings rate, interest rate, exchange rate, and inflation rate, and indirectly with the real economy through the supply movement stimulated by housing demand. Considering the relationship from the opposite direction, it can be thought that financial and economic conditions may affect housing demand and prices.

The above-mentioned functions also point to the economic, sociological, psychological, political, cultural, artistic and religious dimensions of housing. This is why there is a large literature on the concept of housing in various disciplines. In this context, the economic dimensions of housing are also widely discussed in the empirical literature. Factors affecting the supply and demand of housing, the dynamics of change in housing prices, and the relationship between the housing sector in particular and the construction sector in general have been analyzed analytically in many studies. However, when the current empirical literature is examined, it is seen that the issue is generally handled on a demand-side, microlevel and provincial basis. In this study, the factors affecting housing prices are investigated in relation to the macroeconomic structure and at regional (Aegean) level. In a couple of analysis conducted at regional level, either the Aegean Region was excluded from the sample or housing prices were examined within a single factor structure.

\section{Hedonic Housing Price Index}

The word "hedonic" means "based on pleasure" and, economically it refers to the pleasure, satisfaction or benefit that occurs after the consumption of goods and services. Hence, the "hedonic price" can be expressed as the price taken into consideration for a certain level of personal satisfaction. The hedonic price model (HFM) was first used by Waugh (1928) to investigate the effect of land properties on price. However, the term "hedonic price method" was first used by Court (1939) to measure price changes in the automobile market and was popularized by Griliches (1961) and Rosen (1974) (Hülagü et al., 2016; 4). Later, it was used to model price changes in different areas such as real estate market, labor market and public investments (Çetintahra and Çubukçu, 2012; 87). The approach was first applied to price movements in the housing market by Ridker and Henning (1967) (Afşar et al., 2017). 
As with almost every product, quality differences arising from consumer preferences and innovation can be observed in residences. On the other hand, the housing market has a heterogeneous structure by nature and it is not easy to control the impact of quality changes on prices due to high heterogeneity. Therefore, the reason for the changes in house prices can be pure price changes as well as quality changes. Since an increase in house price may result from both these changes, it may be misleading to interpret these increases as a bubble if the price increases are largely due to quality increases.

Central Bank of Turkish Republic (CBRT) has started to calculate the House Price Index (HPI) on a monthly basis since January $2010^{1}$. The price information within the scope of the index is compiled from appraisal reports prepared by real estate appraisal companies for housing loans that are in the approval phase. The data set includes information on the location of the house (province, district, neighborhood information and block number) as well as observable features such as gross usage area, type of heating, construction year, building quality, and whether there is an elevator or security system in the building. This data source allows the determination of the contribution of each quality component to the value (the shadow price of the component), in other words, the willingness to pay for the component, and the calculation of pure price changes by keeping the average properties constant.

HPI, in order to measure changes occurring in the housing market in Turkey, uses a stratified median price method. In the current HPI application, houses with a heterogeneous structure are divided into strata at the most homogeneous level possible with geographic stratification, and the median unit price formed in each lower stratum is weighted with the number of house sales obtained from the General Directorate of Land Registry and Cadastre, and the general price index is reached. In the geographical stratification, districts with sufficient data are determined as stratification, and when there is insufficient data from the districts, calculations are made over all data belonging to that province. On the other hand, when calculating the median unit price of each stratum, extreme values are discarded in order to prevent very expensive and very cheap houses from affecting the index unhealthily. As a result, HPI is calculated using the chain Laspeyres method as follows:

$$
I^{t y}=\frac{\sum_{i} w_{i}^{y} p_{i}^{t y}}{\sum_{i} w_{i}^{y} p_{i}^{12(y-1)}} I^{12(y-1)}
$$

\footnotetext{
${ }^{1}$ The information presented here on the House Price Index depends mainly on Hülagü et al. (2016).
} 
where $y, t$ and $i$ denote the year, month and stratum respectively. $I^{t y}, w_{i}^{y}$ and $p_{i}^{t y}$ represents the price index value, weight, and the median price level. On the other hand, ty means the current month, and 12(y-1) is December of the previous year.

In the characteristic price analysis, hedonic regression models are used to estimate the shadow prices of the observed house characteristics. The log-linear model used is as follows:

$$
\ln p_{n}^{t}=\beta_{0}^{t}+\sum_{k} \beta_{k}^{t} z_{n k}^{t}+\varepsilon_{n}^{t}
$$

where $p_{n}^{t}, z_{n k}^{t}$ and $\beta_{k}^{t}$ denote the price, $k$. feature of the $n$. house and shadow price of $k$. feature of the house respectively. Finally $\varepsilon_{n}^{t}$ is usual error term. This regression is estimated separately for each period and each stratum. Thus, the effect of housing components on the price is enabled to vary between periods and strata. In this way, individual regression coefficient estimates $\left(\hat{\beta}^{t}\right)$ are calculated for all periods (and strata). Then, Laspeyres-type indices are created for each stratum as follows in order to calculate the prices that will occur by keeping the properties constant:

$$
P_{i}^{t}=\frac{\exp \left(\hat{\beta}_{0}^{t}\right) \exp \left[\Sigma_{k} \hat{\beta}_{k}^{t} \bar{z}_{n k}^{0}\right]}{\exp \left(\hat{\beta}_{0}^{0}\right) \exp \left[\Sigma_{k} \hat{\beta}_{k}^{0} \bar{z}_{n k}^{0}\right]}
$$

In the equation, $P_{i}^{t}$ represents the hedonic house price index and $\bar{z}_{n k}^{0}$ denotes the average house characteristics for the base period. The equation in this form expresses the qualityadjusted housing price index, which is calculated by keeping the housing properties constant over time. As can be understood from the equation, since it is quite important to determine the base period, considering as a relatively stable period in the housing market, January 2019 regarded as the base period $(t=0)$ and Housing Price Index (HPI) was constructed for Turkey.

\section{Related Empirical Literature}

There is a wide literature consisting of many studies investigating the factors affecting house prices for the case of Turkey and other countries. Analysis conducted for other countries usually focuses on US' and European cities, while in Turkey large cities such as Istanbul, Ankara and Izmir are more likely to be of interest to researchers. Although the hedonic price model - HPM is by far the most used method, different methods such as multivariate crosssectional regression, case study analysis, causality testing, are also encountered.

When the empirical literature on the determinants of house prices in Turkey is examined, it can be said that the studies are at three different levels: micro, mezzo and macro scale. In micro-scale studies, the relationship between house prices in one (or sometimes several) 
province and the architectural, hardware and spatial characteristics of housing is investigated through HPM. Among these works Üçdoğruk (2001), Yankaya and Çelik (2005), Baldemir et al. (2007), Karagöl (2007), Mutluer (2008), Selim (2008), Cingöz (2010), Kördiş et al. (2014), Cloud et al. (2015), Afşar et al. (2017) can be mentioned for a few. A literature review on the studies in which HFM is used in determining factors affecting house prices was conducted by Çetintahra and Çubukçu (2012), and the studies were evaluated in terms of data structure, data source and explanatory variables set.

In another branch of papers consist from the studies in which the subject is discussed at a macro level for the whole of Turkey. In these studies, the relationship between one or more macroeconomic indicators and house prices is investigated. Although the HPI (House Price Index) created by the CBRT is usually used as an indicator of house prices, the price index constructed by the REIDIN company has also been used in a small number of studies (for example, Hepşen and Aşı1c1, 2013; Erdem et al., 2013, Coşkun et al., 2020). Some of these studies focus on the relationship between house prices and a particular variable (housing credit rate in Akkaş and Sayılgan, 2015; Akpolat, 2020; construction sector confidence index in Çetin and Doğaner, 2017; inflation rate in Sağlam and Abdioğlu, 2020; real exchange rate in Eryüzlü and Ekici, 2020), while other papers examine the relationship between house prices and a battery of macroeconomic variables (see inter alia, Hepşen and Aşıc1, 2013; Karamelikli, 2016; Dilber and Sertkaya, 2016; Y1ldırım and İvrendi, 2017; Akkaya, 2018; Kolcu and Yamak, 2018; Yıldırım and Yağcıbaşı, 2019; Bayır et al., 2019; Gebeşoğlu, 2019; Coşkun et al., 2020; Karadaş and Salihoğlu, 2020). On the other hand, there are also regionallevel studies that can be considered as mezzo-scale (for example, Kayral, 2017; Karaağaç and Altınırmak, 2018; Sağlam and Abdioğlu, 2020). A summary of the empirical papers as to the housing prices and macroeconomic indicator interaction in Turkey can be found at the end of the paper.

Although various explanatory variables sets are used in macro-scale empirical analyses, the most commonly used are GDP, interest rate, inflation and exchange rate. While the effect of GDP, or industrial production which is used as proxy for GDP, on house prices was decisively positive, it was found that inflation rate, the exchange rate and the interest rate on housing loans generally had a negative effect on house prices.

There are other country practices on the subject as well. Apergis (2003), and Apergis and Rezitis (2003) investigated the dynamic effect of macroeconomic factors such as mortgage loan interest rate, inflation and unemployment rates on housing prices in Greece with VAR method based on error correction model. The results obtained reveal that these factors have a 
significant effect on house prices. The majority of the research on house price modeling has been conducted in a linear framework. However, as house prices are driven by the economic activity they could also be expected to exhibit nonlinearities. Katrakilidis and Trachanas (2012) investigated the asymmetric relationship between housing prices, industrial production and inflation in their analysis for Greece and obtained strong evidence for the presence of asymmetry.

In another study, Kiong and Aralas (2019) included a group of macroeconomic factors in their analysis with the ARDL model framework for Malaysia and concluded that all variables except GDP affect house prices. Baffoe-Bonnie (1998) took into account the money supply in addition to interest rates, inflation and unemployment rates in the analysis he conducted at national and regional level in the USA. In the analysis using the VAR method, it was concluded that monetary policy and unemployment affect housing prices at national and regional levels, but inflation is not an effective factor (i. e. neutral). Iacoviello (2000), again, with the help of the (structural) VAR model, in the study of the effects of major macroeconomic variables on housing prices in the example of six EU member countries, he concluded that monetary shocks cause negative shocks, especially in the short term, on housing prices, although their size varies from country to country. Tsatsaronis and Zhu (2004), in their analysis for a group of countries, found that rapid increases and decreases in inflation increase the possibility of wrong pricing in the housing market, while the increase in interest rates leads to increase in house prices. In the study, the importance of stability in financial markets for the housing market is also emphasized.

\section{Empirical Analysis}

\subsection{Variables, Data and Model}

In the analysis, 96 monthly observations for the period January 2012 - December 2019 were used. The relevant literature was taken into consideration while determining the explanatory variables. The dependent variable is the regional hedonic house price index (HPI) calculated by the CBRT as explained above; The set of independent variables is consists of the gold bullion price $(G O L D)$, the BIST100 index value (BIST) representing the stock prices, the Euro/TL exchange rate $(E X C)$ representing the exchange rate, the housing loan interest rate (INT) representing the interest rate, the population of the region $(P O P)$ representing the demand effect, the regional consumer price index $(C P I)$ representing the general price level, consumer confidence index $(C C I)$, and housing unit cost $(H U C)$ representing production cost of house. 


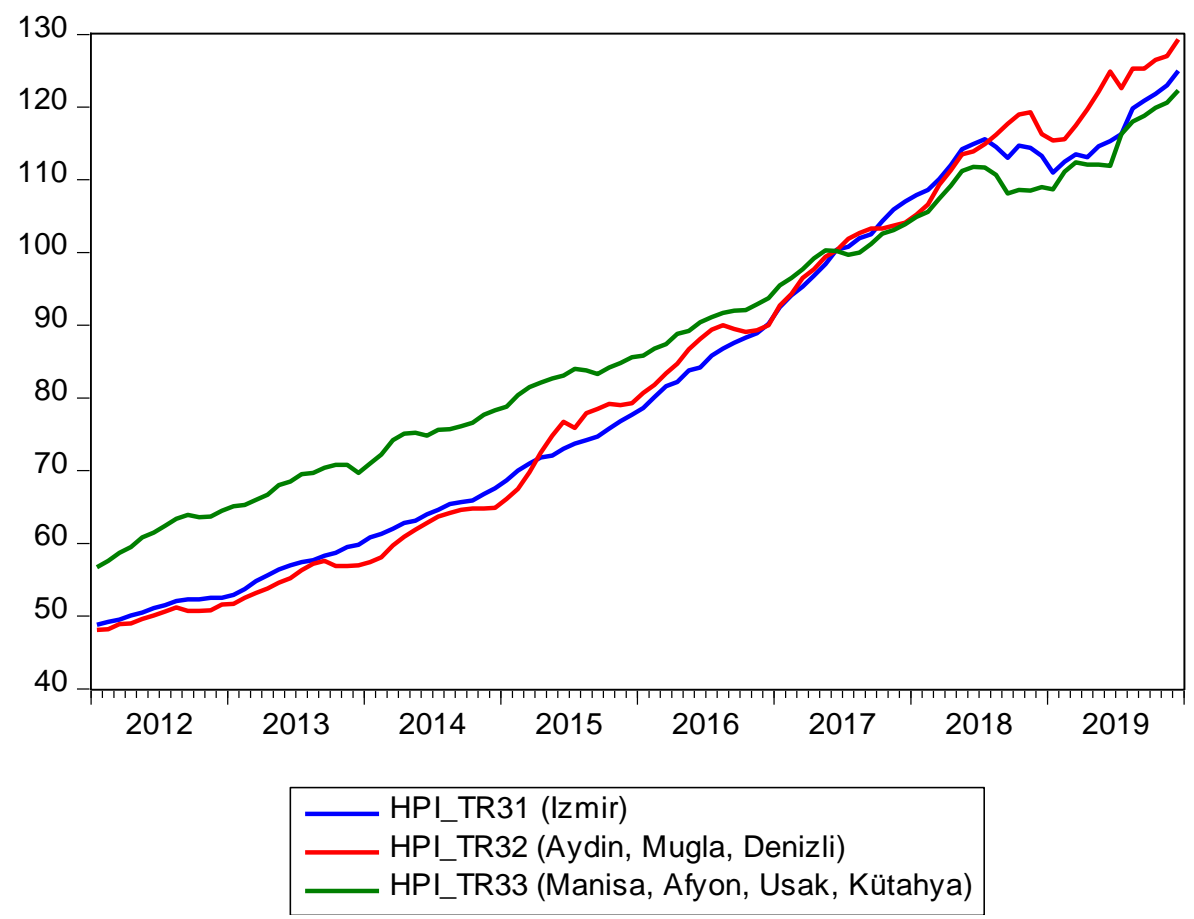

Figure 1. Development of HPI in the Aegean Region during the sample period in terms of sub-regions.

Analyzes were carried out in the Statistical Region Classification (NUTS) level-2. Accordingly, the results have been obtained in terms of three sub-regional units within the Aegean region. These sub-regional units consist of İzmir (TR31), Aydın - Denizli - Muğla (TR32) and Manisa - Uşak - Afyonkarahisar - Kütahya (TR33). As a result of this distinction, the variables of $H P I, P O P$ and $C P I$ consist of values for each sub-region unit. The HUC series reflects the cost of housing units for Izmir. In Turkey, housing unit cost data can only be accessed for Istanbul, Ankara and Izmir. For this reason, this series was used considering that it would be a valid reference indicator for the Aegean region. Population data were compiled from TURKSTAT-APRS (Address-based Population Registration System), and data for other series were compiled from CBRT-EDDS (Electronic Data Delivery System) databases.

Since housing is an expensive consumer good, individuals finance their housing purchases either with their savings they have gained by saving for a long time or by borrowing some amount in addition to their savings. Since the housing loan interest rate reflects the financing cost, an inverse relationship is expected between the interest rate and housing prices. However, as the decrease in the interest rate will increase the demand, it is possible for the prices to increase in the short term due to the demand pressure. Indeed, in summer 2020 after a decline in housing loans in Turkey, such a price increase was observed. Although the said borrowing is generally in the form of using housing loans from banks, it can also be realized 
by borrowing in gold or foreign currency from the milieu. In this respect, it is natural that the gold price, the exchange rate level and the housing loan interest rate are related to the borrowing cost, which seriously affects the housing purchase decisions. The increase in these series can be expected to delay the desire to purchase housing and cause decrease in house prices depending on the decrease in demand. In addition, as gold and foreign currency (mainly US Dollar and Euro in Turkey) are seen as alternative investment tools, especially for small savers, it can be thought that the expectation of increase in gold prices and exchange rates will affect the housing demand for investment purposes and thus the house prices.

House purchasing decision is sensitive to macroeconomic stability like other investment decisions. If the general price level and the rise in inflation are seen as an indicator of deterioration of macroeconomic stability, it is expected to decrease the housing demand and hence prices in the short term (Apergis, 2003). Again, as the rise in prices will decrease households' tendency to save and increase their non-housing expenditures, it will suppress housing demand by creating payment difficulties. The decrease in demand may push sellers who want to deplete the housing stock to decrease prices. However, if the increase in prices continues, it will be inevitable that the rise in construction input prices will affect housing prices in the medium and long term. Since the analysis here tries to capture the long-term relationship, the effect can be expected to be positive. Similarly, stock market performance often serves as a barometer for macroeconomic success. Therefore, the rise in the stock market index may result in an increase in housing demand and hence prices as it will give confidence to investors in macroeconomic stability and success.

Population growth as an indicator of increase in demand capacity, and the increase in the consumer confidence index will cause increase in housing prices. On the other hand, the rise in stock prices, which can be considered as a reflection of the expansion in production and purchasing power, and (once again) macroeconomic stability, may also raise housing prices. The cost of production is a supply-side factor that can have a direct impact on price. Accordingly, the increase in the unit cost of housing has the potential to increase the housing price.

The general form of the model to be predicted is as follows:

$$
\begin{aligned}
H P I_{t}=\beta_{0} & +\beta_{1} G O L D_{t}+\beta_{2} B I S T_{t}+\beta_{3} E X C_{t}+\beta_{4} I N T_{t}+\beta_{5} P O P_{t}+\beta_{6} C P I_{t}+\beta_{7} C C I_{t} \\
& +\beta_{8} H U C_{T}+u_{t}
\end{aligned}
$$

where $\beta_{i}(i=0,1, \ldots, 8)$ indicates the parameters to be estimated, and $u_{t}$ indicates the white noise error term. Among these explanatory variables, GOLD, BIST, EXC, INT and CCI are 
generic, while $P O P, C P I$ and $H U C$ are region-specific variables. The expected signs of the coefficients are as follows:

$$
\beta_{1} \gtrless 0, \beta_{2}>0, \beta_{3} \gtrless 0, \beta_{4}<0, \beta_{5}>0, \beta_{6} \gtrless 0, \beta_{7}>0, \beta_{8}>0
$$

\subsection{Methods of Analyses}

In order to investigate the stationary properties of the series the classical Augmented DickeyFuller (ADF) and Phillips-Perron (PP) unit-root tests were used in the paper. To determine if there exists any long-term relationship between the series, the ARDL method developed by Pesaran et al. (1999, 2001) was used. A generic representation of ARDL model with unrestricted intercept and without trend term can be written as follows:

$$
\Delta y_{t}=\alpha+\sum_{j=1}^{p} \beta_{j} \Delta y_{t-j}+\sum_{i=1}^{k} \sum_{j=1}^{p} \theta_{i j} \Delta x_{i, t-j}+\gamma_{0} y_{t-1}+\sum_{i=1}^{k} \gamma_{i} x_{i, t-1}+\varepsilon_{t}
$$

where $x_{i}(i=1,2, \ldots, k)$ denote explanatory variables, $\beta_{j}$ and $\theta_{i j}$ denote short-run parameters, and $\gamma_{i}$ represent long-run dynamics of the variables. $\varepsilon_{t}$ is white noise disturbance term as usual. The "bounds test" procedure for co-integration is based on testing the null hypothesis of $H_{0}: \gamma_{0}=\gamma_{1}=\gamma_{2}=\cdots=\gamma_{k}=0$ by means of the Wald-type F test. Pesaran et al. (2001) provided two sets of critical values, one for the case of all $\mathrm{I}(0)$ variables and the other for all I(1) variables. If the computed F-statistic goes beyond the upper critical value, the null hypothesis can be rejected which means the series are co-integrated.

If the series are co-integrated, ordinary least squares estimation (static OLS) of the cointegrating vector is consistent, converging at a faster rate than is standard. One important shortcoming of static OLS (SOLS) is that the estimates have an asymptotic distribution that is generally non-Gaussian, exhibit asymptotic bias, asymmetry, and are a function of non-scalar nuisance parameters. Since conventional testing procedures are not valid unless modified substantially, SOLS is generally not recommended if one wishes to conduct inference on the co-integrating vector (Montalvo, 1995; IHS, 2017). To overcome this weakness of SOLS various methods have been developed to estimate the coefficients of the relationship between the co-integrated variables. The best known are Fully Modified OLS (FMOLS) developed by Phillips and Hansen (1990), Canonical Co-integrating Regression (CCR) proposed by Park (1992), and Dynamic OLS (DOLS) methods developed by Stock and Watson (1993).

Let consider the following co-integrating relationship:

$$
y_{t}=X_{t}^{\prime} \beta+D_{t}^{\prime} \gamma+u_{1 t}
$$


where $\left(y_{t}, X_{t}^{\prime}\right)$ is a $n+1$ dimensional time series vector process, $D_{t}=\left(D_{1 t}^{\prime}, D_{2 t}^{\prime}\right)^{\prime}$ are deterministic trend regressors and $n$ stochastic regressors $X_{t}$ are governed by the system of equations:

$$
\begin{aligned}
& X_{t}=\Gamma_{21}^{\prime} D_{1 t}+\Gamma_{22}^{\prime} D_{2 t}+\varepsilon_{2 t} \\
& \Delta \varepsilon_{2 t}=u_{2 t}
\end{aligned}
$$

It is assumed that the innovations $u_{t}=\left(u_{1 t}^{\prime}, u_{2 t}^{\prime}\right)^{\prime}$ are strictly stationary and ergodic with zero mean, contemporaneous covariance matrix $\Sigma$, one-sided long-run covariance matrix $\Lambda$, and covariance matrix $\Omega$.

$$
\begin{aligned}
& \Sigma=E\left(u_{t} u_{t}^{\prime}\right)=\left[\begin{array}{ll}
\sigma_{11} & \sigma_{12} \\
\sigma_{21} & \Sigma_{22}
\end{array}\right] \\
& \Lambda=\sum_{j=0}^{\infty} E\left(u_{t} u_{t-j}^{\prime}\right)=\left[\begin{array}{ll}
\lambda_{11} & \lambda_{12} \\
\lambda_{21} & \Lambda_{22}
\end{array}\right] \\
& \mathbf{\Omega}=\sum_{j=-\infty}^{\infty} E\left(u_{t} u_{t-j}^{\prime}\right)=\left[\begin{array}{ll}
\omega_{11} & \omega_{12} \\
\omega_{21} & \Omega_{22}
\end{array}\right]=\Lambda+\Lambda^{\prime}-\Sigma
\end{aligned}
$$

The modified data can be defined as follows,

$$
y_{t}^{+}=y_{t}-\widehat{\omega}_{12} \widehat{\Omega}_{22}^{-1} \hat{u}_{2}
$$

and estimated bias correction term

$$
\hat{\lambda}_{12}^{+}=\hat{\lambda}_{12}-\widehat{\omega}_{12} \widehat{\Omega}_{22}^{-1} \widehat{\Lambda}_{22}
$$

The FMOLS estimator employs a semi-parametric correction to avoid estimation problems caused by the long-run correlation between the co-integrating equation and stochastic regressors innovations. The resulting estimator is asymptotically unbiased and has fully efficient mixture normal asymptotics allowing for standard Wald tests using asymptotic $\chi^{2}$ statistical inference. Hence the FMOLS estimator can be written as,

$$
\hat{\theta}_{F M O L S}=\left[\begin{array}{c}
\hat{\beta} \\
\hat{\gamma}_{1}
\end{array}\right]=\left(\sum_{t=1}^{T} Z_{t} Z_{t}^{\prime}\right)^{-1}\left(\sum_{t=1}^{T} Z_{t} y_{t}^{+}-T\left[\begin{array}{c}
\hat{\lambda}_{12}^{+\prime} \\
0
\end{array}\right]\right)
$$

where $Z_{t}=\left(X_{t}^{\prime}, D_{t}^{\prime}\right)^{\prime}$.

The CCR estimation procedure is in principle quite similar to FMOLS, but instead employs stationary transformations of the data to eliminate the long-run correlation between the co-integrating equation and stochastic regressors innovations (Belke and Czudaj, 2010). The CCR estimator can be written as, 


$$
\hat{\theta}_{C C R}=\left[\begin{array}{c}
\hat{\beta} \\
\hat{\gamma}_{1}
\end{array}\right]=\left(\sum_{t=1}^{T} Z_{t}^{*} Z_{t}^{* \prime}\right)^{-1}\left(\sum_{t=1}^{T} Z_{t}^{*} y_{t}^{*}\right)
$$

where $Z_{t}^{*}=\left(X_{t}^{*^{\prime}}, D_{t}^{\prime}\right)^{\prime}$ and

$$
\begin{aligned}
& y_{t}^{*}=y_{t}-\left(\widehat{\Sigma}^{-1} \widehat{\Lambda}_{2} \tilde{\beta}+\left[\begin{array}{c}
0 \\
\widehat{\Omega}_{22}^{-1} \widehat{\omega}_{21}
\end{array}\right]\right)^{\prime} \hat{u}_{t} \\
& X_{t}^{*}=X_{t}-\left(\widehat{\Sigma}^{-1} \widehat{\Lambda}_{2}\right)^{\prime} \hat{u}_{t}
\end{aligned}
$$

On the other hand, in the DOLS procedure co-integrating regression equation is augmented with $q$ lags and $r$ leads of $\Delta X_{t}$ such that the error term of the co-integrating equation is orthogonal to the entire history of the stochastic regressor innovations,

$$
y_{t}=X_{t}^{\prime} \beta+D_{1 t}^{\prime} \gamma_{1}+\sum_{j=-q}^{r} \Delta X_{t+j}^{\prime} \delta+v_{1 t}
$$

However, the DOLS estimation procedure works under the assumption that the added lags and leads of $\Delta X_{t}$ completely eliminate the long-run correlation among $u_{1 t}$ and $u_{2 t}$. Hence, the resulting estimator is then given by $\hat{\theta}_{D O L S}=\left(\hat{\beta}^{\prime}, \hat{\gamma}_{1}^{\prime}\right)^{\prime}$ and has the same asymptotic distribution as those derived with the FMOLS and the CCR estimation procedure (Belke and Czudaj, 2010).

\subsection{Stationarity Analysis}

Since seasonal fluctuations, which are frequently seen in high frequency time series, shadow the basic features of the series and make modeling difficult, it is useful to adjust the series from seasonal effect. Since the series used here consist of monthly data, the existence of seasonality effect was investigated first. Seasonality was determined in GOLD, HPI3l, HPI32, CPI31, CPI32, CPI33 and CCI series and the series were adjusted for seasonal effect using the TRAMO / SEATS method.

When investigating the relationship between time series, it is necessary to investigate the stationary properties of the series first, so the stationarity research has been carried out with the ADF and PP unit-root tests. Tests were conducted separately both for with (intercept plus trend) and without (intercept-only) trend specifications. 
Table 1. Unit-root tests results.

\begin{tabular}{|c|c|c|c|c|}
\hline & \multicolumn{2}{|c|}{$A D F$} & \multicolumn{2}{|c|}{$P P$} \\
\hline & $\mathrm{c}$ & $\mathrm{c}+\mathrm{t}$ & $\mathrm{c}$ & $\mathrm{c}+\mathrm{t}$ \\
\hline HPI31 & 1.184 & -2.080 & 1.124 & -2.128 \\
\hline HPI32 & 1.269 & -2.703 & 1.433 & -2.599 \\
\hline HPI33 & 0.426 & -3.054 & 0.416 & -2.062 \\
\hline$G O L D$ & 2.952 & -0.368 & 3.889 & 0.026 \\
\hline$B I S T$ & 0.703 & -2.017 & 0.539 & -1.636 \\
\hline$E X C$ & 0.581 & -1.737 & 0.536 & -1.836 \\
\hline$I N T$ & $-2.869^{* * *}$ & $-3.609^{* *}$ & -2.130 & -2.638 \\
\hline POP31 & -2.141 & -2.397 & -2.168 & -2.393 \\
\hline POP32 & -2.291 & -0.694 & -0.536 & $-4.459^{*}$ \\
\hline POP33 & -0.241 & $-3.541^{* *}$ & 0.001 & $-3.564^{* *}$ \\
\hline CPI31 & 3.206 & 0.163 & 4.678 & 0.281 \\
\hline CPI32 & 3.166 & 0.205 & 3.758 & -0.091 \\
\hline CPI33 & 3.292 & 0.005 & 3.383 & -0.174 \\
\hline$C C I$ & -2.470 & $-3.931^{* *}$ & -2.228 & $-3.909^{* * *}$ \\
\hline$H U C$ & 0.520 & -2.287 & 0.633 & -2.248 \\
\hline$\triangle H P I 31$ & $-6.804^{*}$ & $-7.011^{*}$ & $-6.842^{*}$ & $-7.052^{*}$ \\
\hline$\triangle H P I 32$ & $-5.783^{*}$ & $-6.052^{*}$ & $-7.198^{*}$ & $-7.333^{*}$ \\
\hline$\triangle H P I 33$ & $-7.233^{*}$ & $-7.238^{*}$ & $-6.968^{*}$ & $-6.960^{*}$ \\
\hline$\triangle G O L D$ & $-7.782^{*}$ & $-8.700^{*}$ & $-7.729^{*}$ & $-9.355^{*}$ \\
\hline$\Delta B I S T$ & -2.493 & -2.646 & $-6.598^{*}$ & $-6.764^{*}$ \\
\hline$\triangle E X C$ & $-8.844^{*}$ & $-8.993^{*}$ & $-6.534^{*}$ & $-6.967^{*}$ \\
\hline$\Delta I N T$ & $-6.046^{*}$ & $-6.013^{*}$ & $-5.149^{*}$ & $-5.111^{*}$ \\
\hline$\triangle P O P 31$ & $-9.895^{*}$ & $-9.997^{*}$ & $-9.899^{*}$ & $-10.047^{*}$ \\
\hline$\triangle P O P 32$ & -1.961 & -2.147 & $-10.926^{*}$ & $-10.862^{*}$ \\
\hline$\triangle P O P 33$ & -1.720 & -1.804 & $-10.746^{*}$ & $-10.713^{*}$ \\
\hline$\triangle C P I 31$ & $-3.806^{*}$ & $-5.251^{*}$ & $-5.775^{*}$ & $-6.188^{*}$ \\
\hline$\Delta C P I 32$ & $-3.568^{*}$ & $-5.317^{*}$ & $-5.732^{*}$ & $-6.651^{*}$ \\
\hline$\Delta C P I 33$ & $-3.813^{*}$ & $-7.506^{*}$ & $-5.579^{*}$ & $-6.032^{*}$ \\
\hline$\triangle C C I$ & $-8.546^{*}$ & $-8.499^{*}$ & $-17.181^{*}$ & $-17.059^{*}$ \\
\hline$\triangle H U C$ & $-4.594^{*}$ & $-4.660^{*}$ & $-7.389^{*}$ & $-7.472^{*}$ \\
\hline
\end{tabular}

Notes: $i . * / * * * * *$ denote significance at $1 \% .5 \%$ and $10 \%$ level respectively. ii. $\mathrm{c}$ denotes intercept. $\mathrm{c}+\mathrm{t}$ denotes intercept and trend. iii. $\Delta$ represents first difference of series. iv) Since the ADF and PP tests for the $\triangle B I S T$ and $\triangle P O P 32$ series gave conflicting results. the KPSS test was conducted and it was concluded that both series were stationary. 
In the ADF test the INT series, and in the both tests the trend-added specifications of the POP33 and CCI series appear to be stationary at their level values. Accordingly, the degrees of integration of the series are mixed.

\subsection{Co-integration Analysis}

In the next step, the existence of a long-term significant linear relationship between the series was investigated with the ARDL bounds test that allows different degrees of integration and the results are given in Table 2. As can be seen, the F-statistics calculated for all three subregions exceeds the upper limit value at $1 \%$ significance level. According to these results, the null hypothesis that "there is no co-integration relationship between variables" can be rejected for all three sub-regions.

Table 2. ARDL bounds test results for co-integration.

\begin{tabular}{|c|c|c|c|c|c|}
\hline \multirow{2}{*}{$\begin{array}{l}\text { Dependent } \\
\text { Variable }\end{array}$} & \multirow{2}{*}{$\begin{array}{l}\text { Independent } \\
\text { Variables }\end{array}$} & \multirow{2}{*}{ F value } & \multirow{2}{*}{$\begin{array}{c}\text { Significance } \\
\text { Level }\end{array}$} & \multicolumn{2}{|c|}{ Critical values } \\
\hline & & & & $\mathrm{I}(0)$ & $\mathrm{I}(1)$ \\
\hline HPI31 & $\begin{array}{l}\text { GOLD, BIST } \\
\text { EXC, INT } \\
\text { POP31, } \\
\text { CPI31 } \\
\text { CCI, HUC }\end{array}$ & 3.849 & & & \\
\hline HPI32 & $\begin{array}{l}\text { GOLD, BIST } \\
\text { EXC, INT } \\
\text { POP32, } \\
\text { CPI32 } \\
\text { CCI, HUC }\end{array}$ & 4.832 & $\begin{array}{c}\% 10 \\
\% 5 \\
\% 1\end{array}$ & $\begin{array}{l}1.92 \\
2.17 \\
2.73\end{array}$ & $\begin{array}{l}2.89 \\
3.21 \\
3.90\end{array}$ \\
\hline HPI33 & $\begin{array}{l}\text { GOLD, BIST } \\
\text { EXC, INT } \\
\text { POP33, } \\
\text { CPI33 } \\
\text { CCI, HUC }\end{array}$ & 7.971 & & & \\
\hline
\end{tabular}

According to the results of the co-integration test, there is a significant long-term relationship between the variables in all three sub-regions. Having found out that the variables are co-integrated, the coefficients of long and short-term relationships between variables were estimated by appropriate ARDL models which were determined according to AIC criteria (Table 3). According to the results, the housing loan interest rate and construction cost in the TR31 sub-region and the exchange rate and construction cost in the TR32 sub-region are influential on house prices. In the TR33 sub-region, all variables seem to have a significant effect, except for the exchange rate, stock market index and consumer confidence index. Considering all sub-regions together, the stock market index and the consumer do not affect 
housing prices in any region, while the most striking common factor is the cost of construction. Error correction model estimates indicate that this long-term equilibrium relationship is maintained in all three sub-regions. Findings obtained from diagnostic tests show that the predicted models are acceptable. CUSUM and CUSUMQ tests also reveal that parameters are stable throughout the sample period.

Table 3. Long and short-run relationships between the variables based on ARDL model.

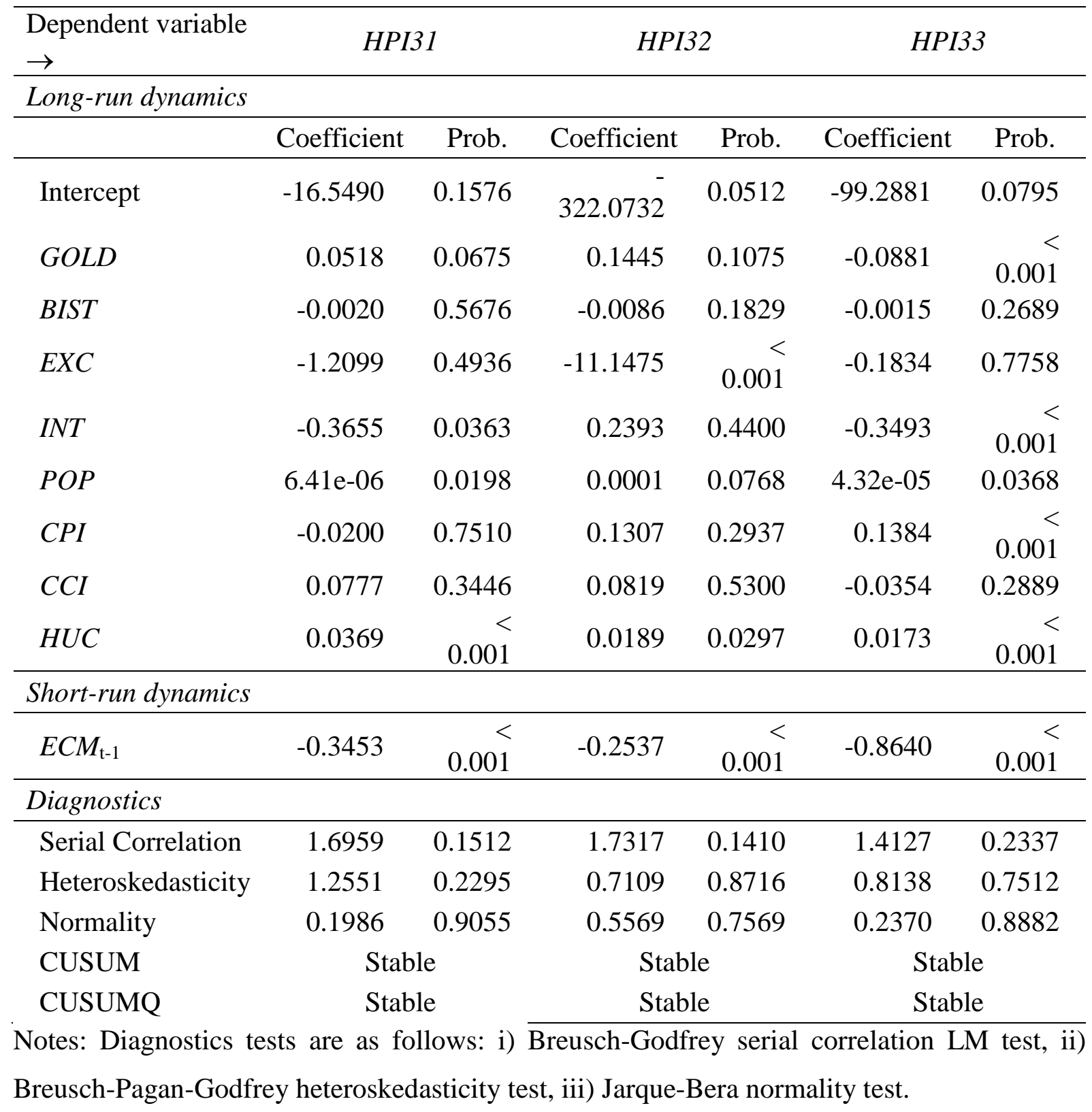

\subsection{Estimating Co-integrated Relationship}

As means for robustness check of the estimated coefficients, three co-integrating regression methods (FMOLS, DOLS, CCR) were applied and results were presented in Table 4. The signs of the predictions obtained are in line with the theoretical expectations. The GOLD 
variable appears to be negatively associated with housing prices only in the TR33 region. $B I S T$ and EXC variables have a significant negative effect only in the TR32 region. The sign of the BIST's coefficient is negative contrary to expectations, but this unexpected effect may be ignored since the value of the coefficient is quite small. The INT variable has a significant effect with the negative sign in the TR31 and TR33 regions, as expected. Depending on the population growth, an increase in housing prices is observed only in the TR33 region, but the impact is weak enough to be negligible. The factors that have a strong influence on house prices in all three sub-regions are the $C P I$ and $H U C$ variables that directly affect the cost of housing. The increase in these variables seems to raise housing prices significantly. $C C I$ has a significant positive effect only in the TR31 region.

When the estimation results are evaluated as a whole, it can be said that house prices in the three sub-regions are fed by somewhat different dynamics. It is seen that in İzmir, which constitutes a large center by far between the three sub-regions and is therefore defined as a sub-region alone, housing prices are not very sensitive to the macroeconomic structure. This situation can be explained by the fact that city rent is more dominant in housing prices in İzmir, which is the third largest city in Turkey.

In the TR32 region consisting of Aydın, Muğla, and Denizli provinces, the intense presence of cottages, which are more prominent as a luxury investment property, can be interpreted as a reason why housing prices in this region are affected by BIST and EXC indicators, which are mostly used as indicators of macroeconomic stability.

Finally, the predictive powers of the explanatory variables and the house price index on each other were examined through Granger causality analysis (see Table 5). The results show that BIST, EXC, INT, CPI and HUC variables are the Granger cause of HPI in all sub-regions, whereas in the opposite direction HPI is only the Granger cause of BIST and INT. Accordingly, it is possible to make predictions about house prices in the short term by looking at the movements in these four variables.

Considering two-way causality, it is understood that HPI in all three sub-regions has a very strong causality relationship with BIST, INT and $H U C$ variables. Variables with the lowest predictive power are $P O P$ and $C C I$. For 8 explanatory variables and 3 sub-regions (24 results in total), 18 causality relationships from variables to $H P I$ are valid, while there are 13 causality relationships from HPI to variables. Based on these findings, it can be said in general that HPI has a lower predictive power against these variables. 
Table 4. Estimations of co-integrated regressions.

\begin{tabular}{|c|c|c|c|c|c|c|c|c|c|}
\hline \multirow{2}{*}{$\begin{array}{c}\text { Method } \\
\rightarrow \\
\text { Dependent } \\
\text { Variable } \\
\rightarrow\end{array}$} & \multicolumn{3}{|c|}{ FMOLS } & \multicolumn{3}{|c|}{$D O L S$} & \multicolumn{3}{|c|}{$C C R$} \\
\hline & HPI31 & HPI32 & HPI33 & HPI31 & HPI32 & HPI33 & HPI31 & HPI32 & HPI33 \\
\hline Intercept & -6.927 & $-87.282^{* *}$ & $-97.76^{* *}$ & $-15.130^{* *}$ & -33.875 & $-147.89^{* *}$ & -6.585 & $-77.781^{* *}$ & $-102.96^{* *}$ \\
\hline$G O L D$ & -0.011 & 0.048 & $-0.091^{*}$ & 0.028 & 0.014 & $-0.101^{*}$ & -0.016 & 0.040 & $-0.093^{*}$ \\
\hline$B I S T$ & 0.001 & $-0.005^{* *}$ & -0.001 & 0.002 & $-0.006^{* *}$ & -0.002 & -0.0001 & $-0.006^{* * *}$ & -0.002 \\
\hline$E X C$ & $-0.958^{* * *}$ & $-4.898^{*}$ & -0.602 & -0.094 & $-9.962^{*}$ & -1.044 & -0.908 & $-5.541^{*}$ & -0.636 \\
\hline$I N T$ & $-0.201^{*}$ & 0.048 & $-0.486^{*}$ & $-0.152^{* * * *}$ & $0.325^{* * *}$ & $-0.337^{*}$ & $-0.213^{*}$ & 0.081 & $-0.478^{*}$ \\
\hline POP31 & $-3.5 e-08$ & & & $3.94 \mathrm{e}-06$ & & & $-2.75 e-07$ & & \\
\hline POP32 & & $3.20 \mathrm{e}-05$ & & & $1.71 \mathrm{e}-06$ & & & $2.72 \mathrm{e}-05$ & \\
\hline РОР33 & & & $4.28 \mathrm{e}-05^{*}$ & & & $6.00 \mathrm{e}-05^{* *}$ & & & $4.45 \mathrm{e}-05^{* *}$ \\
\hline CPI31 & $0.062^{*}$ & & & -0.011 & & & $0.065^{*}$ & & \\
\hline CPI32 & & $0.090^{* *}$ & & & $0.259^{*}$ & & & $0.112^{* *}$ & \\
\hline CPI33 & & & $0.153^{*}$ & & & $0.144^{*}$ & & & $0.153^{*}$ \\
\hline$C C I$ & $0.126^{*}$ & -0.004 & -0.058 & $0.128^{*}$ & 0.116 & -0.040 & $0.133^{*}$ & 0.008 & -0.054 \\
\hline$H U C$ & $0.032^{*}$ & $0.030^{*}$ & $0.018^{*}$ & $0.033^{*}$ & $0.030^{*}$ & $0.018^{*}$ & $0.032^{*}$ & $0.031^{*}$ & $0.018^{*}$ \\
\hline
\end{tabular}


Table 5. Pairwise Granger causality test results.

\begin{tabular}{lccccccc}
\hline Sub-region $\rightarrow$ & \multicolumn{3}{c}{ TR31 } & & TR32 & \multicolumn{3}{c}{ TR33 } \\
\hline Null hypothesis $\downarrow$ & Obs & $\begin{array}{c}\text { F- } \\
\text { statistic }\end{array}$ & Prob. & $\begin{array}{c}\text { F- } \\
\text { statistic }\end{array}$ & Prob. & $\begin{array}{c}\text { F- } \\
\text { statistic }\end{array}$ & Prob. \\
\hline GOLD does not Granger cause HPI & 88 & 5.4678 & $\mathrm{p}<0.05$ & 1.6963 & 0.1143 & 2.5631 & 0.0163 \\
HPI does not Granger cause GOLD & 88 & 1.2020 & 0.3104 & 0.9361 & 0.4927 & 2.1325 & 0.0436 \\
\hline BIST does not Granger cause HPI & 88 & 3.0385 & 0.0054 & 3.2112 & 0.0036 & 3.7974 & 0.0009 \\
HPI does not Granger cause BIST & 88 & 4.4203 & 0.0002 & 2.9477 & 0.0067 & 2.8629 & 0.0081 \\
\hline EXC does not Granger cause HPI & 88 & 3.0056 & 0.0058 & 2.8835 & 0.0077 & 2.1972 & 0.0376 \\
HPI does not Granger cause EXC & 88 & 1.2143 & 0.3033 & 1.8186 & 0.0877 & 1.5820 & 0.1457 \\
\hline INT does not Granger cause HPI & 88 & 2.1599 & 0.0410 & 3.4410 & 0.0021 & 2.4055 & 0.0234 \\
HPI does not Granger cause INT & 88 & 2.7600 & 0.0103 & 2.1498 & 0.0419 & 6.3354 & $\mathrm{p}<0.05$ \\
\hline POP does not Granger cause HPI & 88 & 0.6496 & 0.7334 & 3.1767 & 0.0039 & 0.9243 & 0.5019 \\
HPI does not Granger cause POP & 88 & 0.5473 & 0.8168 & 1.5587 & 0.1529 & 2.5964 & 0.0150 \\
\hline CPI does not Granger cause HPI & 88 & 6.0589 & $\mathrm{p}<0.05$ & 2.7057 & 0.0117 & 2.2731 & 0.0317 \\
HPI does not Granger cause CPI & 88 & 2.0691 & 0.0503 & 1.0064 & 0.4391 & 1.0283 & 0.4232 \\
\hline CCI does not Granger cause HPI & 88 & 1.5018 & 0.1721 & 1.9766 & 0.0619 & 1.8034 & 0.0907 \\
HPI does not Granger cause CCI & 88 & 1.5087 & 0.1697 & 2.3782 & 0.0249 & 2.4868 & 0.0194 \\
\hline HUC does not Granger cause HPI & 88 & 2.8437 & 0.0085 & 3.6577 & 0.0013 & 4.1017 & 0.0005 \\
HPI does not Granger cause HUC & 88 & 9.5292 & $\mathrm{p}<0.05$ & 1.9694 & 0.0629 & 5.2077 & $\mathrm{p}<0.05$ \\
\hline
\end{tabular}

Notes: $i$. It was determined that the appropriate delay length is 8 according to Akaike and Hannan-Quinn criteria. $i i$. Test statistics with p-values less than $5 \%$ were shaded. 


\section{Conclusion}

Housing, as a durable consumer good, has an important share in household expenditures and wealth, whether for housing or investment purposes. On the other hand, the housing sector occupies an important place in the economy when considered together with its forward and backward connections. For this reason, it is inevitable that the housing sector has an important relationship with the economic structure both as a cause and effect. The dynamism in house prices that emerged as a result of this interaction deserves to be emphasized and examined due to the importance of the sector. Determining the impact of macroeconomic conditions on house prices in countries such as Turkey, where the population and, accordingly, housing demand and supply are growing rapidly, is also important for the more efficient operation of the housing market and for predicting supply/demand shocks.

Although the factors affecting house prices are often considered in terms of the characteristics of the house and the environmental conditions in which the house is located, and therefore in a framework that can be characterized as micro-level, there are also studies on the relationship between house prices and macroeconomic structure. But in the case of Turkey, such macro-level studies are quite scarce. In this study, the relationship between house prices and macroeconomic factors was discussed in the example of the Aegean region.

For this purpose, the relationship between a series of macroeconomic variables and the Hedonic House Price Index, which reflects the changes in house prices, has been analyzed through econometric methods. The findings obtained reveal that housing prices in the Aegean Region by sub-regional units exhibit different behaviors against macroeconomic indicators. While housing prices in the Izmir metropolitan region are more resistant to the change in macroeconomic indicators, it is observed that the sensitivity is higher in the TR33 sub-region. On the other hand, the fact that the consumer confidence index, which is a reflection of consumers' expectations for the future of the macroeconomic structure, has a determining effect only on housing prices in the Izmir sub-region can be explained by the fact that investment / purchasing decisions in this region are more related to the general economic structure. It can be said that this difference in behavior between regions is due to differences in housing markets and city-specific characteristics of each sub-region.

Common results for all three sub-regions appear in terms of the effects of inflation and housing unit costs. As expected, the increase in the regional inflation rate has an upward effect on 
housing prices in each sub-region. The high coefficient significance (below 1\%) can be interpreted as high inflation sensitivity in house prices. Within the whole set of explanatory factors the cost of housing stands out as the factor that has a stable effect in all three sub-regions. This difference between regions is also reflected in the causality relationships between variables and house prices. While there is a causality relationship across the Aegean Region from stock market, exchange rate, loan interest rate, general price level and housing costs to housing prices, the relationships in other directions differ by sub-regions.

Summing up, although they display similar characteristics in terms of geography, culture, and demography, it can be said that housing price dynamics in the cities of the Aegean Region are similar to some extent, but they also have some important distinctive characteristics. At this point, it should not be ignored the effects of city rents, which are effective especially in city centers and metropolitan areas, and price bubbles that appear from time to time and regionally on housing prices. These phenomena have the potential to blur the relationship between house prices and macroeconomic variables. Nevertheless, it would be beneficial to keep in mind these behavioral characteristics in the housing supply and demand researches for the Aegean Region. 
Karagöz, K., Özkubat, G. / Journal of Yasar University, 2021, 16/62, 867-889

\section{REFERENCES}

Afşar, A., Yılmazel, Ö. and Yılmazel, S. (2017). "Determining the Parameters of Housing Prices Using Hedonic Model: A Case Study in Eskişehir", Journal of Selçuk University Institute of Social Sciences, 37, 195-205. (In Turkish)

Akkaş, M. E. and Sayılgan, G. (2015). "Housing Prices and Mortgage Interest Rate: Toda-Yamamoto Causality Test". Journal of Economics, Finance \& Accounting, 2 (4), 572-583. (In Turkish)

Akkaya, M. (2018). "An Analysis of Factors Affecting Hedonic Housing Pricing Index”, Journal of Dokuz Eylül University Faculty of Economic and Administrative Science, 33 (2), 435-454. (In Turkish)

Akpolat, A. G. (2020). "Asymmetric Causality between Housing Prices and Mortgage Interest Rates in Turkey: 2010:1-2020:3 Monthly Period", International Journal of Social and Economic Studies, 1 (1), 67-83. (In Turkish)

Apergis, N. (2003). "Housing Prices and Macroeconomic Factors: Prospects within the European Monetary Union", International Real Estate Review, 6 (1), 63-74.

Apergis, N. and Rezitis, A. (2003). "Housing Prices and Macroeconomic Factors in Greece: Prospects within the EMU", Applied Economics Letters, 10, 561-565.

Baffoe-Bonnie, J. (1998). "The Dynamic Impact of Macroeconomic Aggregates on Housing Prices and Stock of Houses: A National and Regional Analysis", Journal of Real Estate, Finance and Economics, 17 (2), 179197.

Baldemir, E., Kesbiç, C. Y. and İnci, M. (2008). "Estimating Hedonic Demand Parameters in Real Estate Market: The Case of Muğla". Journal of Social Sciences, 20, 41-66. (In Turkish)

Bayır, M., Güvenoğlu, H. and Kutlu, Ş. Ş. (2019). "An Empiricial Analysis on the Determinants of Housing Prices", II. International Conference on Empirical Economics and Social Science (ICEESS' 19), June 20-22, 2019, Balıkesir - Turkey (In Turkish)

Belke, A. and Czudaj, R. (2010). "Is Euro Area Money Demand (Still) Stable? - Cointegrated VAR versus Single Equation Techniques", DIW Berlin Discussion Papers No. 982.

Canbay, Ş. and Mercan, D. (2020). "An Econometric Analysis about the Relationships between Housing Prices, Growth and Macroeconomic Variables in Turkey", Journal Management and Economics Research, 18 (1), 176-200. (In Turkish)

Cingöz, A. (2010). "Analysis of Closed-Cite House Prices in Istanbul”, Journal of Social Sciences, 2, 129-139. (In Turkish)

Coşkun, Y., Seven, Ü., Ertuğrul, H. M. and Alp, A. (2020). "Housing price dynamics and bubble risk: the case of Turkey", Housing Studies, 35 (1), 50-86.

Court, A. (1939). Hedonic Price Indexes with Automotive Examples. (in) The Dynamics of Automobile Demand, 99 117, General Motors Corporation, New York.

Çetintahra, G. E. and Çubukçu, E. (2012). "A Literature Review on Research on Housing Prices with the Hedonic Price Model". Planlama, 1-2, 86-98. (In Turkish)

Çetin, G. and Doğaner, A. (2017). "The Relationship Between Construction Sector and Housing Price Index: An Empirical Analysis for Turkey”, Journal of Economic Policy Researches, 4 (2), 155-165. (In Turkish)

Dilber, İ. and Sertkaya, Y. (2016). "An Analysis for the Determinants of Housing Prices in Turkey after the 2008 Financial Crisis”, Journal of Social Sciences of Muş Alparslan University, 4 (1), 11-30 (In Turkish).

Eryüzlü, H. and Ekici, S. (2020). "Housing Price Index and Real Exchange Rate Relations: The Case of Turkey", Journal of Economics Business and Political Researches, 5 (12), 97-105 (In Turkish).

Gebeşoğlu, P. F. (2019). "House Price Dynamics in Turkey", Journal of Yaşar University, Special Issue on Applied Economics and Finance, 14, 100-107.

Griliches, Z. (1961). Hedonic price indexes for automobiles: An econometric analysis of quality change. National Bureau of Economic Research and University of Chicago. 0-87014-072-8, 173-196.

Hepşen, A. and Aşıc1, M. (2013). "The Association between Current Account Deficit and House Prices in Turkey", Journal of Applied Finance and Banking, 3 (3), 65-79.

Hülagü, T., Kızılkaya, E., Özbekler, A. G. and Tunar, P. (2016). A Hedonic House Price Index for Turkey. CBRT Working Paper, No. 2016-03.

HIS Global Inc. (2017). EViews 10 User's Guide II.

Iacoviello, M. (2000). House Prices and the Macroeconomy in Europe: Results from a Structural VAR Analysis. European Central Bank, Working Paper No. 18.

Karaağaç, G. A. and Altınırmak, S. (2018). "The Causality Relationship between Turkey House Price Index, Level Based House Price Index and Selected Variables”, Karadeniz, 39, 222-240. (In Turkish) 
Karadaş, H. A. and Salihoğlu, E. (2020). "The Effect of Selected Macroeconomic Variables on Housing Prices: The Case of Turkey", International Journal of Economic and Social Research, 16 (1), 63-80. (In Turkish)

Karagöl, T. (2007). A Study of Housing Prices in Ankara. MSc Thesis. Middle East Technical University, Ankara.

Karamelikli, H. (2016). "Linear and Nonlinear Dynamics of Housing Price in Turkey", Ekonomia, 46, 81-98.

Katrakilidis, C. and Trachanas, E. (2012). "What Drives Housing Price Dynamics in Greece: New Evidence from Asymmetric ARDL Cointegration", Economic Modelling, 29, 1064-1069.

Kayral, İ. E. (2017). "Research of the Factors Affecting Istanbul, Ankara and Izmir Housing Price Changes", Çukurova University Journal of Faculty of Economic and Administrative Science, 21 (1), 65-84. (In Turkish)

Kiong, W. V. and Aralas, S. (2019). "Macroeconomic Variables and Housing Price in Malaysia", Proceedings of the International Conference on Economics 2019 (ICE 2019), 23-34.

Kolcu, F. and Yamak, N. (2018). "Short and Long-Run Effects of Income and Interest Rate on House Prices", International Journal of Economic and Administrative Studies, Special Issue, 141-152. (In Turkish)

Kördiş, G., Işık, S. and Mert, M. (2014). "The Estimation of Determinants of House Prices in Antalya: Hedonic Pricing Model”. Akdeniz University Journal of Faculty of Economic and Administrative Science, 14 (28), 103-132. (In Turkish)

Montalvo, J. G. (1995). "Comparing cointegrating regression estimators: Some additional Monte Carlo results", Economics Letters, 48, 229-234.

Mutluer, D. (2008). "Deriving Real Estate Prices: Country Samples and an Application for Turkey". TíSK Akademi, 2008/II, 240-278. (In Turkish)

Park, J. Y. (1992). “Canonical Cointegrating Regressions”, Econometrica, 60, 119-143.

Pesaran, M. H. and Shin, Y. R. (1999). "An Autoregressive Distributed Lag Modelling Approach to Cointegration Analysis", in Econometrics and Economic Theory in the 20th Century: The Ragnar Frisch Centennial Symposium, ed. By S. Strom, Cambridge University Press, Cambridge, chap. 11, 371-413.

Pesaran, M. H., Shin, Y. R. and Smith, R. J. (2001). "Bounds Testing Approaches to the Analysis of Level Relationships", in Special Issue in Honour of J. D. Sargan - Studies in Empirical Macroeconometrics, ed. by D. F. Hendry and M. H. Pesaran, Journal of Applied Econometrics, 16, 289-326.

Phillips, P. C. B. and Hansen, B. E. (1990). "Statistical Inference in Instrumental Variables Regression with I(1) Processes", Review of Economic Studies, 57, 99-125.

Ridker, R.G. and Henning, J.A. (1967). "The Determinants of Residential Property Values with Special Reference to Air Pollution", The Review of Economics and Statistics, 49, 246- 257.

Rosen, S. (1974). "Hedonic Prices and Implicit Markets: Product Differentiation in Pure Competition". The Journal of Political Economy, 82, 34-55.

Sağlam, C. and Abdioğlu, Z. (2020). "The Relationship between Hedonic House Prices and Consumer Prices in Turkey: Panel Data Analysis", Journal of Yaşar University, 15/57, 117-128. (In Turkish)

Selim, S. (2008). "Determinants of House Prices in Turkey: A Hedonic Regression Model". Journal of Doğuş University, 9 (1), 65-76.

Stock, J. H. and M. Watson (1993). "A Simple Estimator of Cointegrating Vectors in Higher Order Integrated Systems", Econometrica, 61, 783-820.

Tsatsaronis, K. and Zhu, H. (2004). "What Drives Housing Price Dynamics: Cross-country Evidence". BIS (Bank of International Settlements) Quarterly Review, March-2004, 65-78.

Üçdoğruk, Ş. (2001). "Factors Affecting Property Prices in Izmir Province: Hedonic Approach". Journal of Dokuz Eylül University Faculty of Economic and Administrative Science, 16 (2), 149-161. (In Turkish)

Waugh, F. W. (1928). "Quality Factors Influencing Vegetable Prices". Journal of Farm Economics, 10 (2), 185-196.

Yankaya, U. and Çelik, H. M. (2005). "Modeling the Effects of Izmir Metro on Housing Prices Using Hedonic Price Method". Journal of Dokuz Eylül University Faculty of Economic and Administrative Science, 20 (2), 6179. (In Turkish)

Yıldırım, M. O. (2017). Analyzing Housing Market Dynamics in Turkey's Economy. PhD Thesis, Pamukkale University, Enstitute of Social Sciences, Denizli, Turkey. (In Turkish)

Yıldırım, M. O. and Ivrendi, M. (2017). "House Prices and the Macroeconomic Environment in Turkey: The Examination of a Dynamic Relationship", Economic Annals, 62 (215), 81-110.

Yıldırım, M. O. and Yağcıbaşı, M. (2019). "The Dynamics of House Prices and Fiscal Policy Shocks in Turkey", Economic Annals, 64 (220), 39-59. 
Appendix: Summary of the empirical papers related to Turkish housing market.

\begin{tabular}{|c|c|c|c|c|}
\hline Paper & Variables & Method & Findings & Sample Period \\
\hline $\begin{array}{l}\text { Hepşen and } \\
\text { Aş1c1, (2013) }\end{array}$ & $\begin{array}{l}\text { HPI, GDPPC, } \\
\text { INF, FD, IR, } \\
\text { CAD }\end{array}$ & OLS & $\begin{array}{l}\text { INF, FD, IR, } \\
\text { CAD are } \\
\text { effective }\end{array}$ & $\begin{array}{l}\text { 2007:07- } \\
\text { 2012:03 }\end{array}$ \\
\hline $\begin{array}{l}\text { Karamelikli } \\
(2016)\end{array}$ & $\begin{array}{l}\text { HPI, UEMP, IR, } \\
\text { GDP, INF }\end{array}$ & NARDL & $\begin{array}{l}\text { UEMP, IR, GDP, } \\
\text { INF are effective }\end{array}$ & $\begin{array}{l}\text { 2010:01- } \\
\text { 2016:02 }\end{array}$ \\
\hline $\begin{array}{l}\text { Akkaş and } \\
\text { Sayılgan (2015) }\end{array}$ & HPI, IR & $\begin{array}{l}\text { Toda-Yamamoto } \\
\text { causality test }\end{array}$ & $\mathrm{HPI} \rightarrow \mathrm{IR}$ & $\begin{array}{l}\text { 2010:01- } \\
\text { 2015:04 }\end{array}$ \\
\hline $\begin{array}{l}\text { Coşkun et al. } \\
(2020)\end{array}$ & $\begin{array}{l}\text { HPI, CCI, HRI, } \\
\text { IR }\end{array}$ & $\begin{array}{l}\text { ARDL, OLS, } \\
\text { FMOLS, DOLS }\end{array}$ & $\begin{array}{l}\text { CCI, HRI, IR are } \\
\text { effective }\end{array}$ & $\begin{array}{l}2007: 06- \\
2014: 12 \\
\end{array}$ \\
\hline Akpolat (2020) & HPI, IR & $\begin{array}{l}\text { Hatemi-J } \\
\text { asymmetric } \\
\text { causality test }\end{array}$ & $\mathrm{HPI} \leftrightarrow \mathrm{IR}$ & $\begin{array}{l}\text { 2010:01- } \\
\text { 2020:03 }\end{array}$ \\
\hline $\begin{array}{l}\text { Eryüzlü and } \\
\text { Ekici (2020) }\end{array}$ & HPI, EXC & $\begin{array}{l}\text { Dolado- } \\
\text { Lütkepohl } \\
\text { causality test }\end{array}$ & $\begin{array}{l}\mathrm{HPI}^{-} \rightarrow \mathrm{EXC}^{+} \\
\mathrm{EXC}^{+} \rightarrow \mathrm{HPI}^{-} \\
\mathrm{HPI}^{+} \\
\mathrm{EXC}^{-} \rightarrow \mathrm{HPI}^{-}\end{array}$ & $\begin{array}{l}\text { 2010:01- } \\
\text { 2019:09 }\end{array}$ \\
\hline $\begin{array}{l}\text { Kolcu and } \\
\text { Yamak (2018) }\end{array}$ & HPI, GDP, IR & ARDL & GDP is effective & $\begin{array}{l}\text { 2010:01- } \\
\text { 2017:09 }\end{array}$ \\
\hline Kayral (2017) & $\begin{array}{l}\text { HPI, GOLD, } \\
\text { USD, EURO, } \\
\text { BIST, INF }\end{array}$ & OLS & $\begin{array}{l}\text { BIST and INF } \\
\text { are effective for } \\
\text { Istanbul }\end{array}$ & $\begin{array}{l}\text { 2010:01- } \\
\text { 2016:08 }\end{array}$ \\
\hline $\begin{array}{l}\text { Karadaş and } \\
\text { Salihoğlu (2020) }\end{array}$ & $\begin{array}{l}\text { HPI, CPI, CV, } \\
\text { IR, EXC, IPI, } \\
\text { WPIC }\end{array}$ & ARDL & $\begin{array}{l}\text { CPI, CV, IR, } \\
\text { EXC, IPI are } \\
\text { effective }\end{array}$ & $\begin{array}{l}\text { 2012:12- } \\
\text { 2018:07 }\end{array}$ \\
\hline $\begin{array}{l}\text { Karaağaç and } \\
\text { Altınırmak } \\
(2018)\end{array}$ & $\begin{array}{l}\text { HPI, IPI, CPI, } \\
\text { EXC, CI, EMP, } \\
\text { UEMP }\end{array}$ & $\begin{array}{l}\text { Granger } \\
\text { causality test }\end{array}$ & $\begin{array}{l}\mathrm{HPI} \leftrightarrow \mathrm{CI} \\
\mathrm{HPI} \rightarrow \mathrm{IPI}, \mathrm{EMP} \\
\mathrm{CPI} \rightarrow \mathrm{HPI}\end{array}$ & $\begin{array}{l}\text { 2010:01- } \\
\text { 2017:12 }\end{array}$ \\
\hline Akkaya (2018) & $\begin{array}{l}\text { HPI, GOLD, } \\
\text { EXC, BIST, INF, } \\
\text { IPI, CI, UEMP, } \\
\text { CLI }\end{array}$ & $\begin{array}{l}\text { ARDL, Granger } \\
\text { causality test }\end{array}$ & $\begin{array}{l}\text { GOLD, UEMP, } \\
\text { EXC, BIST } \rightarrow \\
\text { HPI } \\
\text { HPI } \rightarrow \text { IPI } \\
\mathrm{HPI} \leftrightarrow \text { CI }\end{array}$ & $\begin{array}{l}\text { 2010:01- } \\
\text { 2017:03 }\end{array}$ \\
\hline $\begin{array}{l}\text { Gebeşoğlu } \\
\text { (2019) }\end{array}$ & $\begin{array}{l}\text { HPI, GDP, EXC, } \\
\text { BIST, IR }\end{array}$ & ARDL & $\begin{array}{l}\text { GDP, EXC, } \\
\text { BIST are } \\
\text { effective }\end{array}$ & $\begin{array}{l}\text { 2010:01- } \\
\text { 2018:08 }\end{array}$ \\
\hline $\begin{array}{l}\text { Yildırım and } \\
\text { İvrendi (2017) }\end{array}$ & $\begin{array}{l}\text { HPI, MS, IPI, IR, } \\
\text { GDP, BIST, HP, } \\
\text { CP }\end{array}$ & SVAR & $\begin{array}{l}\text { Important effects } \\
\text { of monetary } \\
\text { policy shocks on } \\
\text { housing market }\end{array}$ & $\begin{array}{l}\text { 2002:Q1- } \\
\text { 2015:Q3 } \\
\text { 2003:01- } \\
\text { 2016:11 }\end{array}$ \\
\hline $\begin{array}{l}\text { Yıldırım and } \\
\text { Yağcıbaşı (2019) }\end{array}$ & $\begin{array}{l}\text { HPI, PS, IR, } \\
\text { GDP }\end{array}$ & ARDL & $\begin{array}{l}\text { PS, IR, GDP are } \\
\text { effective }\end{array}$ & $\begin{array}{l}\text { 2010:01- } \\
\text { 2017:04 }\end{array}$ \\
\hline $\begin{array}{l}\text { Çetin and } \\
\text { Doğaner (2017) }\end{array}$ & HPI, CSCI & $\begin{array}{l}\text { Granger } \\
\text { causality test }\end{array}$ & $\mathrm{CSCI} \rightarrow \mathrm{HPI}$ & $\begin{array}{l}\text { 2011:01- } \\
\text { 2017:03 }\end{array}$ \\
\hline
\end{tabular}




\begin{tabular}{|l|l|l|l|c|}
\hline $\begin{array}{l}\text { Dilber and } \\
\text { Sertkaya (2016) }\end{array}$ & $\begin{array}{l}\text { HPI, EXC, INF, } \\
\text { IR }\end{array}$ & $\begin{array}{l}\text { Granger } \\
\text { causality test, } \\
\text { VAR }\end{array}$ & $\begin{array}{l}\text { No long-run } \\
\text { relationship } \\
\text { EXC } \rightarrow \text { HPI }\end{array}$ & $\begin{array}{c}\text { 2008Q1- } \\
\text { 2014Q4 }\end{array}$ \\
\hline $\begin{array}{l}\text { Bayır et al. } \\
(2019)\end{array}$ & $\begin{array}{l}\text { HPI, GDP, MS, } \\
\text { INF, USD }\end{array}$ & ARDL & $\begin{array}{l}\text { GDP, MS, INF, } \\
\text { USD are } \\
\text { effective }\end{array}$ & 2011-2018 \\
\hline $\begin{array}{l}\text { Sağlam and } \\
\text { Abdioğlu (2020) }\end{array}$ & HPI, CPI & Panel ARDL & $\begin{array}{l}\text { Long-run } \\
\text { relationship } \\
\text { between HPI and } \\
\text { CPI }\end{array}$ & $\begin{array}{c}2010: 01- \\
2018: 02\end{array}$ \\
\hline
\end{tabular}

Note: HPI: House price index, IR: Interest rate, FD: Financial depth, GDPPC: GDP per capita, CAD: Current account deficit, INF: Inflation rate, CCI: Construction cost index, HRI: Housing rent index, CP: Construction permits, BIST: BIST 100 Index, EXC: Real exchange rate, GOLD: Gold price, USD: US Dollar/TL exchange rate, EURO: Euro/TL exchange rate, CPI: Consumer price index, CV: Credit volume, IPI: Industrial production index, WPIC: Construction sector wholesale price index, EMP: Employment, UEMP: Unemployment, CI: Consumer confidence index, CLI: CBRT - Composite leading indicators index, HP: Housing permits, MS: Broad money supply, PS: Public spending, CSCI: Construction sector confidence index, MCV: Mortgage credit volume 